\title{
LOGISTYKA W SYTUACJACH KRYZYSOWYCH W ASPEKCIE BEZPIECZEŃSTWA RUCHU DROGOWEGO - WYBRANE PROBLEMY
}

Zarys treści. W artykule przedstawiono wybrane elementy działań logistycznych podejmowanych w sytuacjach kryzysowych. Zaprezentowano propozycję systematyzacji wszystkich zagrożeń, przedstawiając przy tym szczegółowy podział tych związanych z żywiołami. Odniesiono się do wybranych elementów problematyki sytuacji kryzysowych w ruchu drogowym, przedstawiając stan za lata 1990-2010, a także prognozy ofiar śmiertelnych związanych z ruchem drogowym do roku 2013.

Sło a kluc zow e: bezpieczeństwo, logistyka, kryzys, sytuacje kryzysowe, zagrożenia, żywioły.

„Bezpieczeństwa nie dają prawa natury ani zjednoczenie nielicznych ludzi czy rodzin, ani wielka mnogość, o ile nie kieruje nią jedna wola”.

Thomas Hobbes 


\section{WSTĘP}

Dzisiejsze mass media przyzwyczaiły nas do postrzegania globalnego świata, kontynentu, państwa, a nawet najbliższego lokalnego zakątka przez permanentne prezentowanie zdarzeń mających znamiona kryzysu gospodarczego, politycznego, społecznego, ekologicznego, naturalnego jako sytuacji trwałych, chronicznych czy też powtarzalnych. Kryzysy tego typu przyjmujemy jako coś normalnego, typowego, coś, co nieprędko zniknie z mapy problemów otaczającej nas rzeczywistości.

Od pierwszych dekad XIX w., a w zasadzie w burzliwym XX stuleciu społeczeństwo odeszło od optymistycznego myślenia w kategoriach postępu, przechodząc do pojmowania globalnej rzeczywistości w formie dużo bardziej pesymistycznej (myślenia w kategoriach kryzysu). Jakie to ma przełożenie na świadomość obywateli? Wynikiem kryzysu są postawy zwątpienia, rozczarowania, zagubienia, bezsilności, zatrata sensu życia, zanik myślenia perspektywicznego, zerwanie poczucia ciągłości z tradycją, prywatyzacja celów i ignorowanie spraw publicznych (Sztompka, 2002, s. 446) na rzecz partykularnych interesów osobistych, korporacyjnych czy partyjnych.

Już w odległej przeszłości, sięgającej Juliusza Cezara w roku 45 przed naszą erą, można doszukać się pierwszych konkretnych poczynań w zakresie zwiększenia bezpieczeństwa w ruchu drogowym. Ten władca imperium rzymskiego wydał pierwszy zanotowany przepis dotyczący uspokojenia ruchu drogowego, zakazujący wjazdu na drogi Rzymu wszelkich pojazdów, łącznie z końmi, w ciągu dnia i pozwalający im na pojawianie się w mieście dopiero nocą (Gapiński, 2008, s. 27). Wiek XX to postęp nauki i techniki, w którym rozwiązano wiele problemów politycznych, społecznych i ekonomicznych. Jednakże nie uporano się z wypadkami drogowymi, których liczba jest ciągle zatrważająca. Wypadki drogowe ciągle przypominają wstydliwą chorobę społeczną, z którą rządy nie zawsze potrafią sobie poradzić.

Życie i zdrowie ludzkie to nadrzędne wartości, dlatego zapewnienie bezpieczeństwa ruchu drogowego jest podstawowym światowym, unijnym, krajowym i lokalnym priorytetem. Kwestia bezpieczeństwa drogowego dotyczy wszystkich obywateli i wszyscy powinniśmy przyczynić się do jego zapewnienia. Holistyczne podejście do tego problemu wymaga również rozpatrywania jego wszystkich aspektów, także w kontekście logistycznym. 


\section{BEZPIECZEŃSTWO I JEGO POSTRZEGANIE}

Bezpieczeństwo jest naczelną potrzebą i nadrzędną wartością człowieka, grup społecznych, etnicznych, jest również podstawową potrzebą państw i systemów międzynarodowych, a także ich deklarowanym celem. Pojęcie „bezpieczeństwo" (łac. securitas) występuje w zasadzie w każdej dyscyplinie naukowej i w zależności od płaszczyzny i celów badań jest ono odpowiednio interpretowane. Historycznie bezpieczeństwo znane jest ludzkości od zarania jej dziejów. Niektórzy twierdzą nawet, że potrzeba bezpieczeństwa była nieodzowną potrzebą powstania państwa (Pieprzny, 2009, s. 13).

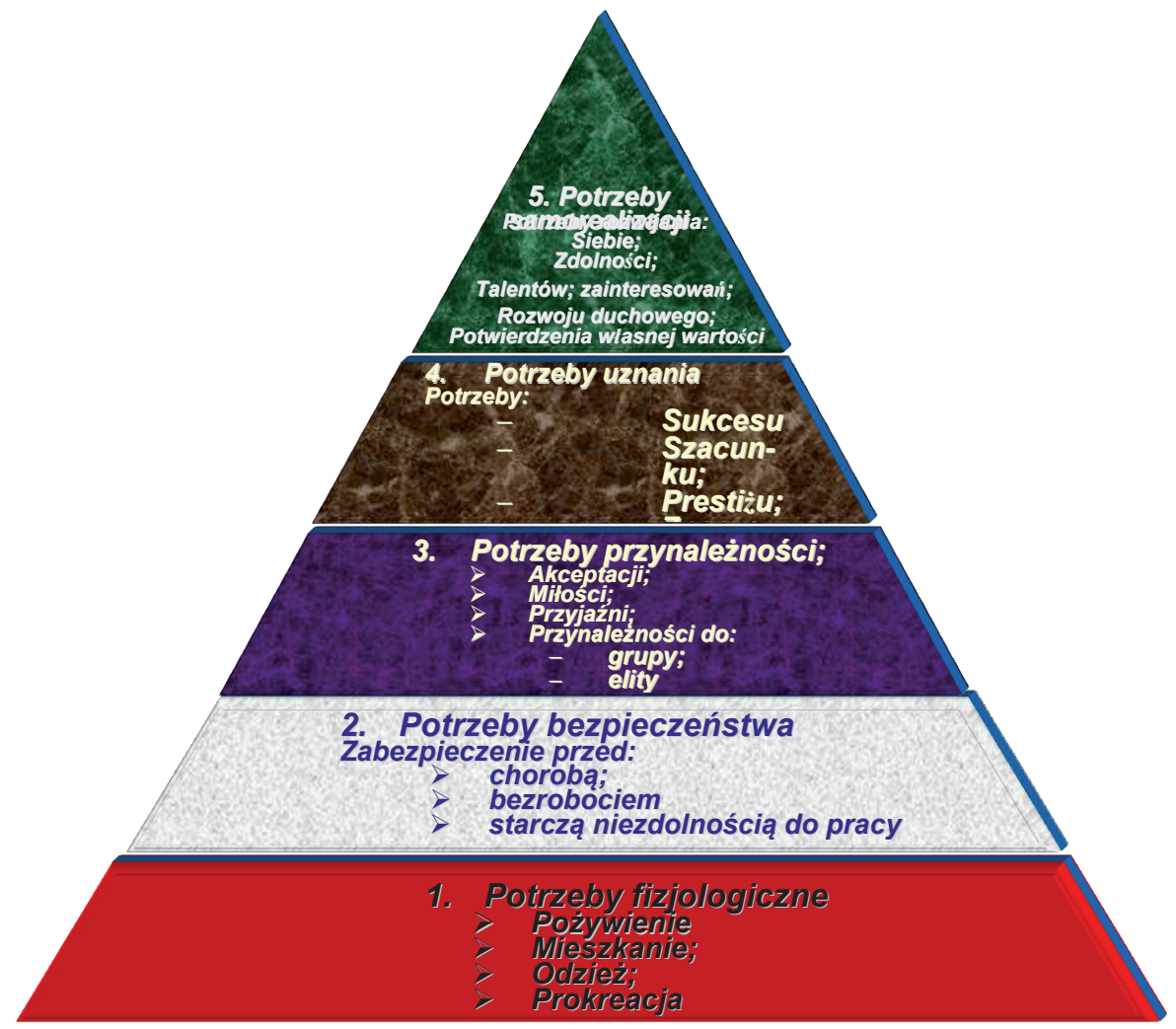

Rysunek 2. Umiejscowienie ryzyka w systemie potencjalnych zagrożen. Układ: środowisko-człowiek-maszyna

Źródło: opracowanie własne. 
Bezpieczeństwo kojarzy się z porządkiem, spokojem oraz zdolnością do zorganizowanego i szybkiego reagowania wobec naruszeń prawa, które zachodzą we współczesnym świecie. Podmiotem bezpieczeństwa jest człowiek wraz z jego wartościami (moralnymi i materialnymi), traktowany jako jednostka społeczna lub zbiorowość społeczna o różnym charakterze więzi i uwarunkowań organizacyjnych. W hierarchii potrzeb człowieka określonej przez kultowego w tym zakresie i wielokrotnie cytowanego Abrahama Maslowa bezpieczeństwo jest drugą z podstawowych potrzeb człowieka, które są potrzebne mu do życia.

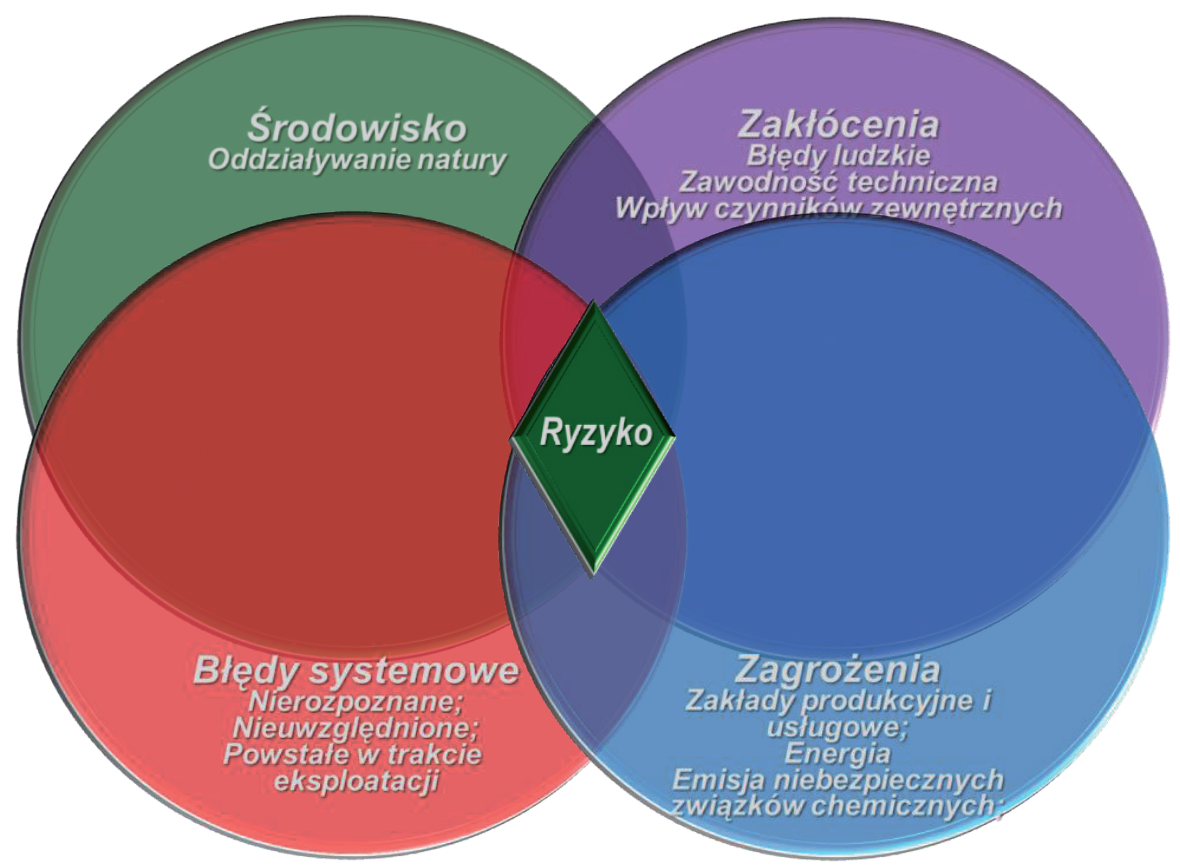

Rysunek 2. Umiejscowienie ryzyka w systemie potencjalnych zagrożeń. Układ: środowisko-człowiek-maszyna

Źródło: opracowanie własne.

\section{TYPOLOGIA WYBRANYCH ZAGROŻEŃ}

Z pojęciem „bezpieczeństwo" ściśle związane jest pojęcie „zagrożenie”, które jest jego antonimem. Człowiek, grupa społeczna, państwo, organizacja międzynarodowa starają się oddziaływać na swoje otoczenie, by usuwać, 
a przynajmniej oddalać zagrożenia, eliminując własny lęk, obawy, niepokój i niepewność (Słownik terminów z zakresu psychologii dowodzenia i zarzadzania, 2000, s. 17). Bezpieczeństwo pozostaje w ścisłym związku z zagrożeniami i oznacza zdolność przeciwstawiania się im.

Zdaniem Jana Strelaua (Strelau, 2003, s. 433) efektem niezaspokojenia ludzkich potrzeb jest: „,brak stabilności w otoczeniu, chaos, konflikty społeczne, deficyty ekonomiczne, a ponadto różnego rodzaju bodźce zagrażające".

Zagrożenia (bezpieczeństwo) można podzielić wg kilku kryteriów:

1. Czasu:

- okres pokoju,

- okres wojny.

2. Obszaru:

- globalne,

- międzynarodowe,

- narodowe,

- regionalne.

3. Stosunku do obszaru państwa:

- zewnętrzne,

- wewnętrzne.

4. Dziedziny, w jakiej występują:

- militarne,

- polityczne,

- energetyczne,

- ekologiczne,

- informatyczne,

- społeczne,

- kulturowe,

- socjalne,

- strukturalne,

- personalne.

Na rysunku zaprezentowano systematykę zagrożeń wg różnych kryteriów, które możemy spotkać współcześnie (mogą przynieść szkody dla człowieka jako jednostki, ale również dla społeczności). 
[172]

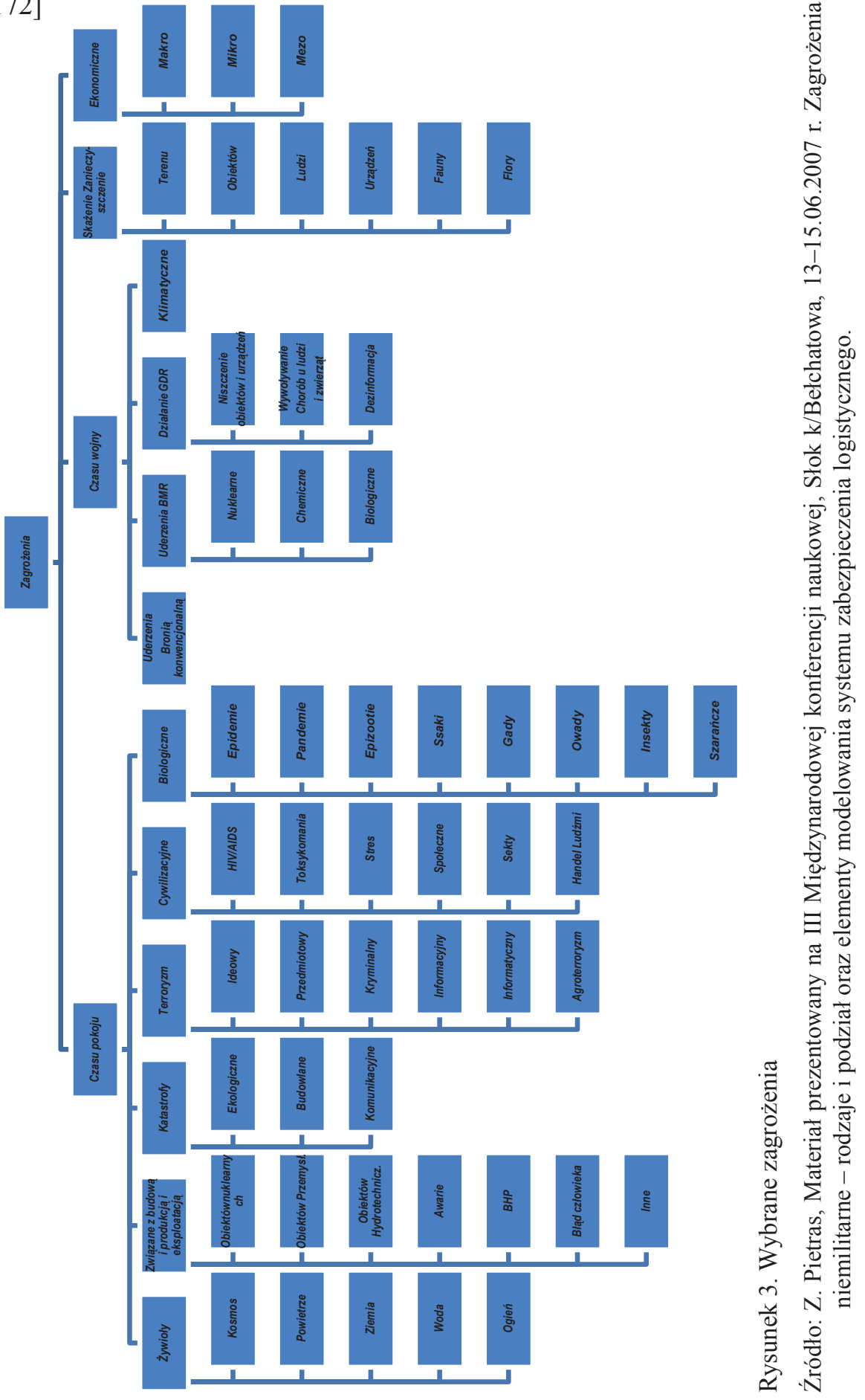


Dokonując klasyfikacji zagrożeń, musimy zdawać sprawę z ich „,jakości” i ilości. Wspominając o ciągłych zmianach czynników zagrożeń, możemy mieć współcześnie do czynienia z całą gamą zagrożeń wynikających z konfliktów zbrojnych, związanych z żywiołami (rysunek 4), będących często skutkiem nieprzestrzegania praw przyrody przez człowieka.

Mogą to być zagrożenia będące efektem rozwoju terroryzmu, dewastacji środowiska naturalnego, niesprawiedliwego podziału dóbr, uzależnień (alkoholizm, nikotynizm, lekomania, narkotyki, od internetu, telewizji), skutkiem przestępczości, chorób.

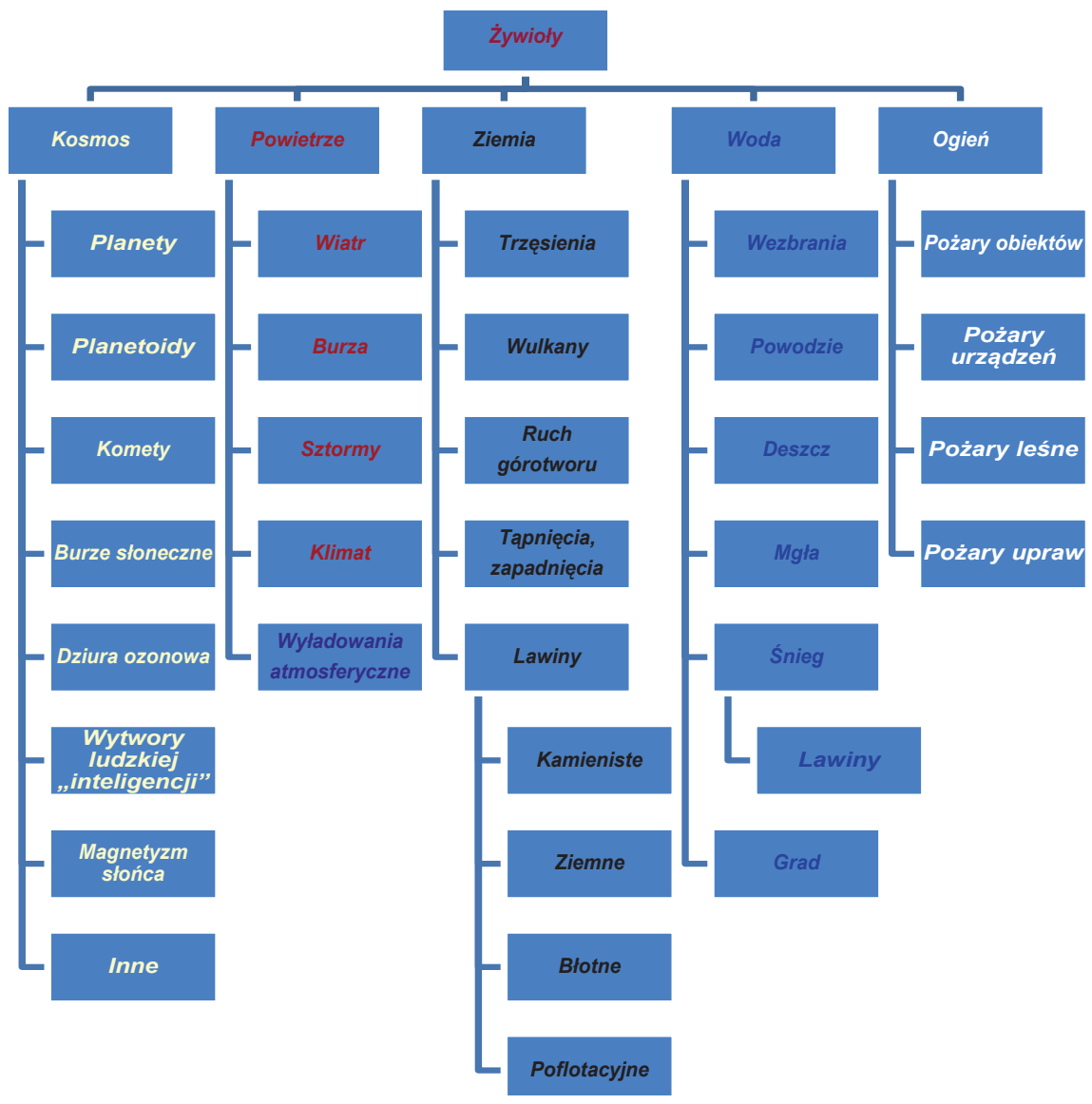

Rysunek 4. Wybrane żywioły

Źródło: Z. Pietras, Materiał prezentowany na III Międzynarodowej konferencji naukowej, Słok k/Bełchatowa, 13-15.06.2007 r. Zagrożenia niemilitarne - rodzaje i podział oraz elementy modelowania systemu zabezpieczenia logistycznego. 
Na rysunkach 3 i 4 przedstawiono tylko część zagrożeń, rozwinięcie ich to kilkaset różnych sytuacji, problemów, które z chwilą zaistnienia należy szybko (pod presją czasu) rozwiązać. W dalszej części artykułu przedstawione zostaną wybrane elementy działalności logistycznej w sytuacjach kryzysowych dotyczących transportu drogowego.

\section{KRYZYS, SYTUACJA KRYZYSOWA}

Punktem wyjściem dla rozważań o problematyce zarządzania kryzysowego w Polsce jest pojęcie samego kryzysu. Słowo „kryzys” wywodzi się z greckiego krino co w wolnym tłumaczeniu oznacza wybór, decydowanie, zmaganie się, walkę, w której konieczne jest działanie pod wpływem czasu. „Kryzys” w języku angielskim rozwija takie parametry, jak: urazowość, subiektywne konsekwencje urazu w postaci negatywnych przeżyć. W związku z powyższym „kryzys” to moment przełomowy do zmian na lepsze lub na gorsze, istotne emocjonalne zdarzenie.

Historia tego pojęcia jest o tyle interesująca, że częściowo odeszło ono od swojego pierwotnego znaczenia - „stan przejściowy, o kluczowym, decydującym znaczeniu dla dalszego rozwoju, jakieś szczególne zagęszczenie i wyostrzenie alternatyw w przyszłości" (Sztompka, 2002, s. 446).

$\mathrm{W}$ takim znaczeniu pojęcie kryzys używane jest wciąż w medycynie, gdzie może oznaczać przesilenie, z którego są tylko dwa wyjścia - chory wyzdrowieje lub nie.

Dla dalszych rozważań można przyjąć definicję lepiej oddającą jego społeczny charakter.

Przez sytuację kryzysową należy rozumieć sytuację wpływającą negatywnie na poziom bezpieczeństwa ludzi, mienia w znacznych rozmiarach lub środowiska, wywołującą znaczne ograniczenia w działaniu właściwych organów administracji publicznej ze względu na nieadekwatność posiadanych sił i środków ${ }^{1}$. To sytuacja będąca następstwem zagrożenia dla stanu bezpieczeństwa państwa (rys. 5), jednak w takim stopniu, że użyte środki niezbędne do zapewnienia lub przywrócenia bezpieczeństwa nie uzasadniają wprowadzenia żadnego ze stanów nadzwyczajnych, o których mowa w art. 228 ust. 1 Konstytucji Rzeczypospolitej Polskiej. Niestety sytuacji kryzysowych nie jesteśmy w stanie zliczyć. Może być ich tyle, ile ludzkich zachowań, ponieważ

1 Ustawa o zarządzaniu kryzysowym z dnia 26 kwietnia 2007 r., Dz.U.07.89.590, art. 3 , pkt 1 . 
ludzkie zachowania nie zawsze dadzą się przewidzieć. Sytuacje kryzysowe powodujące „kryzys” możemy ograniczać oraz zmniejszyć jego skutki. Natomiast nie da się ich wyeliminować do końca.

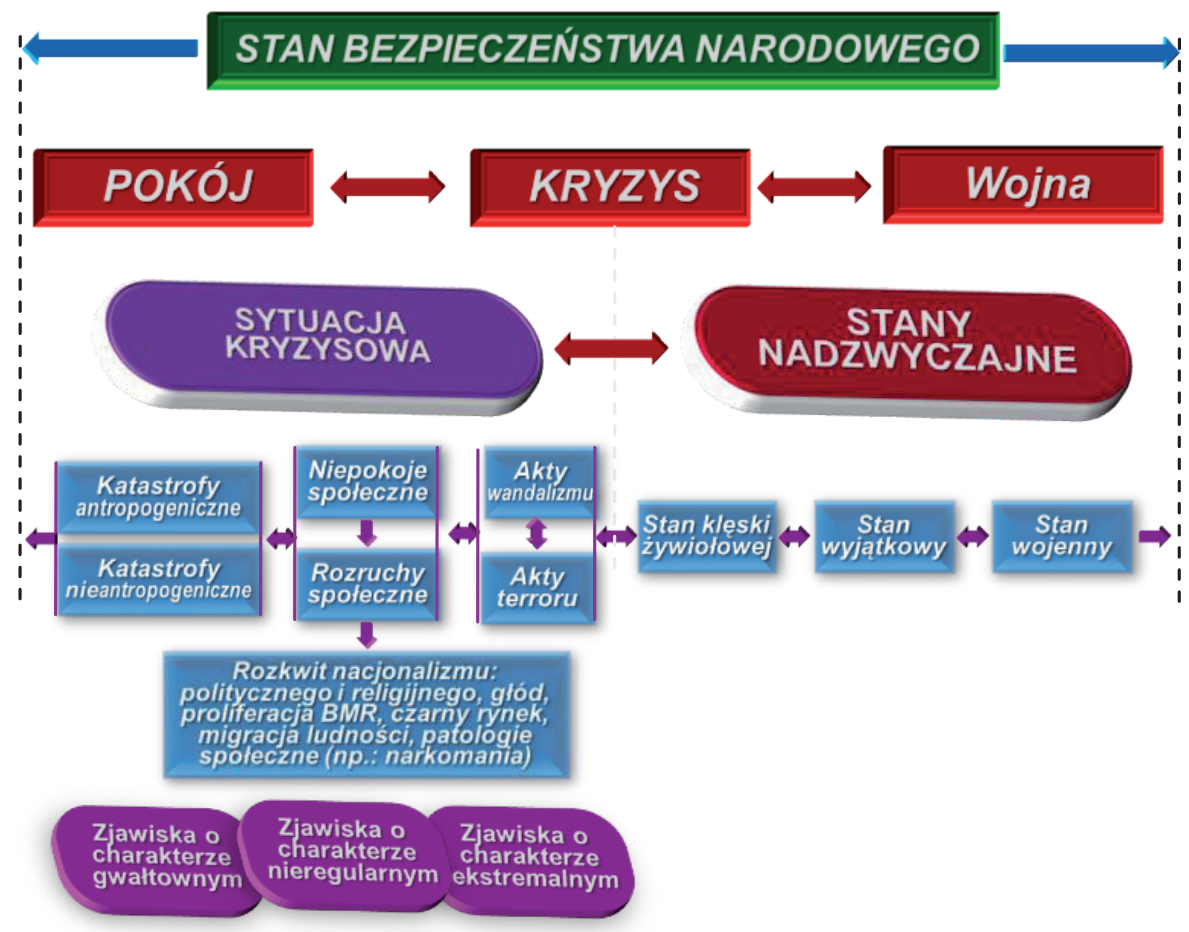

Rysunek 5. Usytuowanie sytuacji kryzysowej w stanie bezpieczeństwa państwa

Źródło: Z. Pietras, opracowanie na podstawie: E. Nowak, 2005, s. 11.

\section{WYBRANE ELEMENTY \\ KIEROWANIA I ZARZĄDZANIA LOGISTYCZNEGO W SYTUACJ KRYZYSOWEJ}

Logistyka w sytuacjach kryzysowych zajmuje się nie tylko kwestiami zaopatrzenia i świadczenia usług specjalistycznych oraz gospodarczo-bytowych na rzecz ludności poszkodowanej, ale również zabezpieczeniem logistycznym podmiotów prowadzących działania ratownicze i prewencyjne, a także aspektami logistycznymi działań związanych z odbudową obiektów infrastruktury krytycznej, obiektów infrastruktury transportowej, drogowej itp. Jednak pro- 
blematyka ta postrzegana jest $\mathrm{z}$ innego logistycznego punktu widzenia i towarzyszą jej inne określone, specyficzne procedury (Nowak, Nowak, 2009, s. 7).

Obecnie w działalności służb odpowiedzialnych za zarządzanie kryzysowe dominuje pogląd (Nowak, 2008, s. 28) o czterech fazach zabezpieczenia logistycznego (rys. 6):

1. Faza wstępna; charakteryzuje ją nagły rozwój zagrożenia, którego charakter może przerastać wielkość potencjału logistycznego przygotowanego w danym rejonie na czas kryzysu.

2. Faza integracji, w której następuje zespolenie wszystkich dostępnych sił i środków logistycznych adekwatnych do wielkości realizowanych zadań logistycznych.

3. Faza usuwania skutków, w której do akcji wkraczają inne niż ratownicze służby, takie jak przedsiębiorstwa transportowe, firmy remontowe.

4. Faza przywracania stanu pierwotnego, w której następuje odtworzenie zniszczonej infrastruktury, pracy służb pomocy socjalnej i innych.

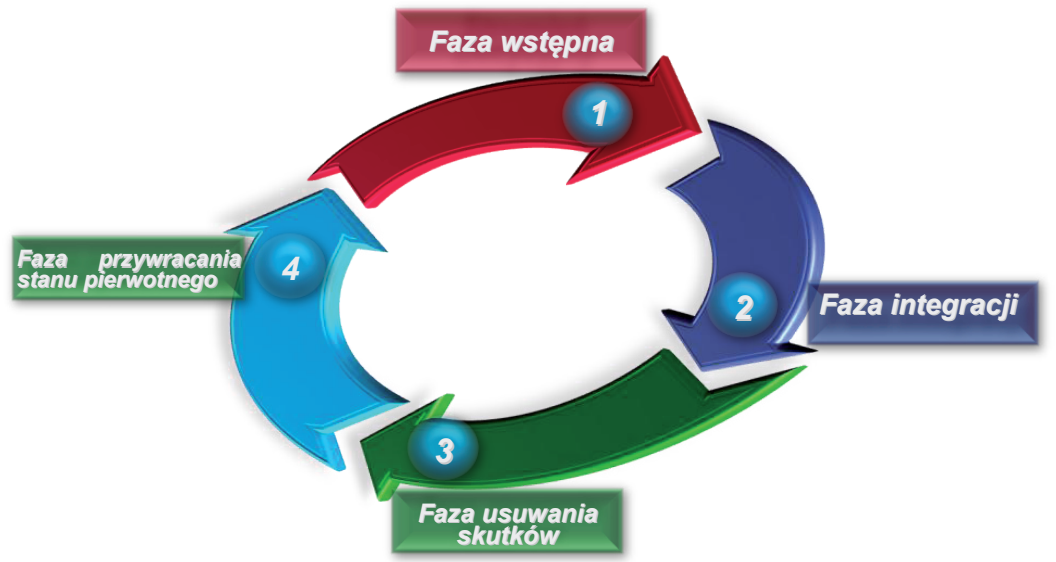

Rysunek 6. Standardy działania w przewidywaniu zagrożenia

Źródło: opracowanie własne.

Wydaje się jednak, że celem nadrzędnym logistyki w sytuacjach kryzysowych winno być zapewnienie przetrwania wszystkim poszkodowanym oraz niosącym pomoc (rys. 7). 


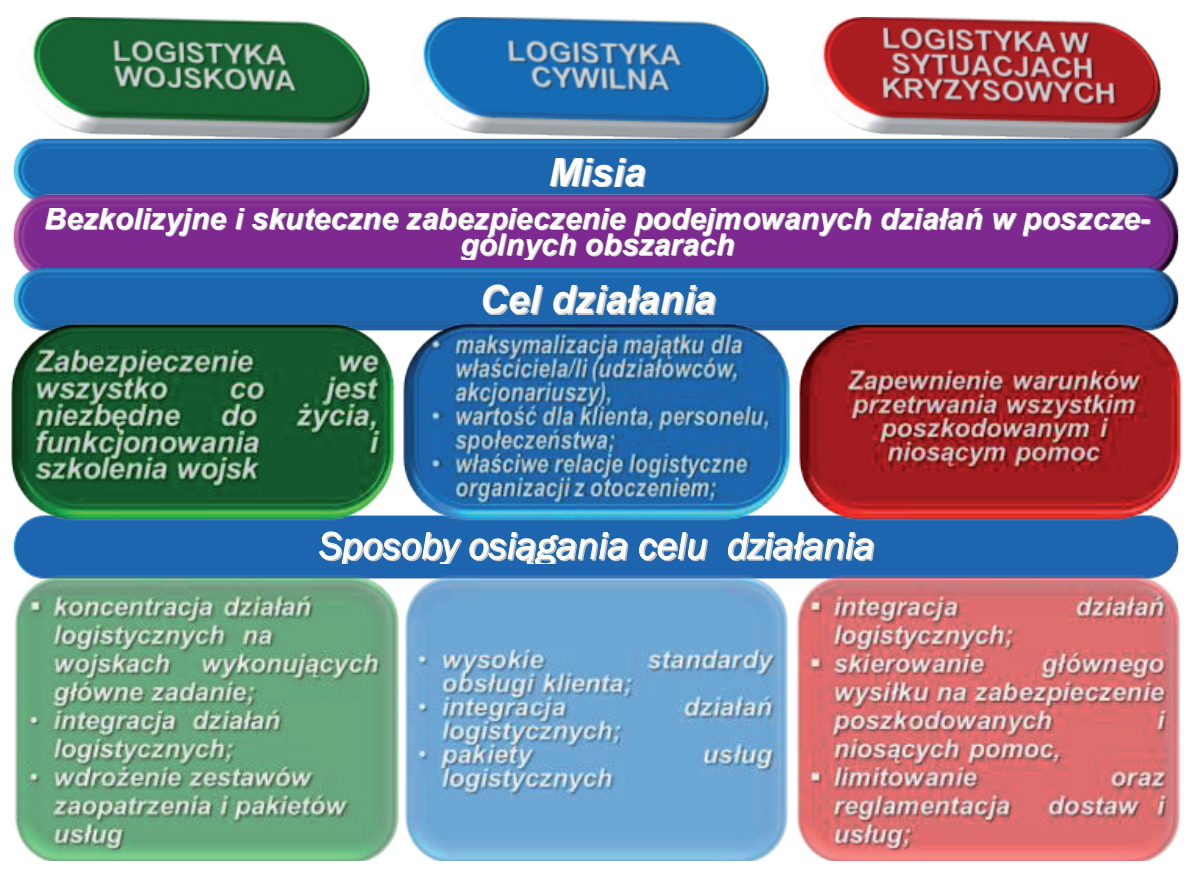

Rysunek 7. Misja i zadania logistyki sytuacji kryzysowych

Źródło: Z. Pietras, por.: Nowak, 2008.

Wielu praktyków w standardach działania w przewidywaniu zagrożenia przewiduje cztery etapy działania (rys. 8):

1. Zapobieganie.

2. Przygotowanie.

3. Monitorowanie i reagowanie.

4. Odtwarzanie.

Na podstawie doświadczenia, obserwacji z ćwiczeń, przeprowadzonych analiz wydaje się, że najbardziej właściwy jest podział na pięć etapów rozpatrywanych w standardach działania dla mogących zaistnieć zagrożeń uwzględniających (rys. 9):

1. Rozpoznawanie, analizowanie i planowanie.

2. Przygotowanie, szkolenie.

3. Profilaktyka zapobiegania.

4. Reagowanie.

5. Odtwarzanie.

Taki podział zapewni nam w miarę pełne przygotowanie do wszelkiego rodzaju nowych zagrożeń mogących powstać na danym terenie. 


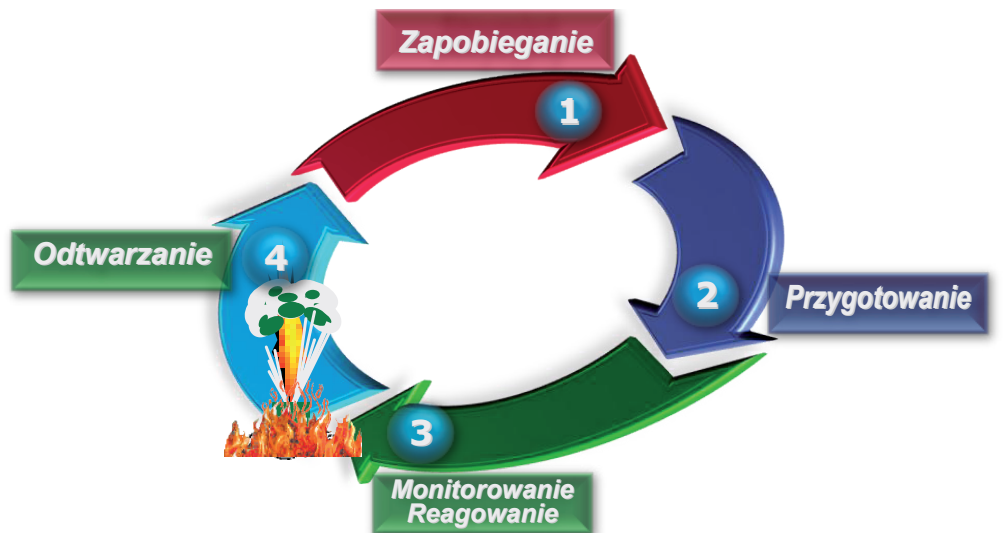

Rysunek 8. Standardy działania w przewidywaniu zagrożenia Źródło: opracowanie własne.

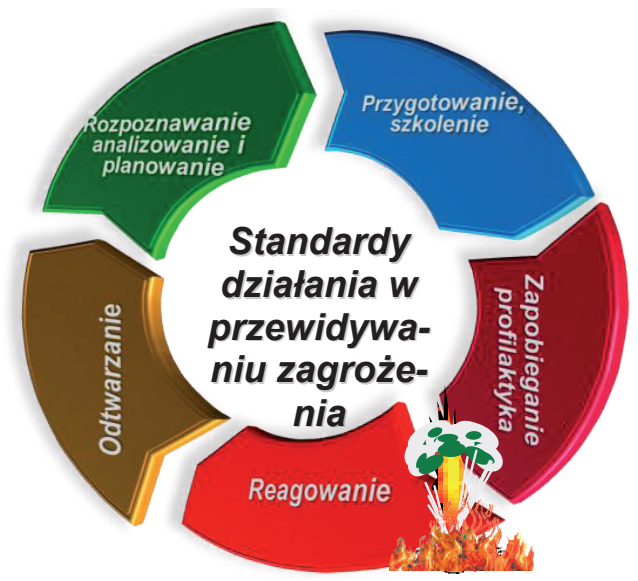

Rysunek 9. Propozycja standardów działania w przewidywaniu zagrożenia Źródło: opracowanie własne.

\section{WYBRANE ASPEKTY LOGISTYKI W SYTUACJACH KRYZYSOWYCH ZWIAZZANYCH Z RUCHEM DROGOWYM}

Ze względu na obszerny zakres i różnorodność zagrożeń nie sposób w tak krótkim materiale opisać (uwzględnić) całej problematyki sytuacji kryzyso- 
wych. Biorąc powyższe pod uwagę, podjęto próbę przedstawienia wybranych aspektów logistyki w kontekście wypadków drogowych.

Liczba ofiar śmiertelnych (wykres 1) od 1990 do 2011 roku oscylowała na poziomie ok. 6100 osób osiągając max ok. 7900 zabitych w 1991 r., a najniższy poziom ok. 3760 ofiar śmiertelnych w 2010 r.

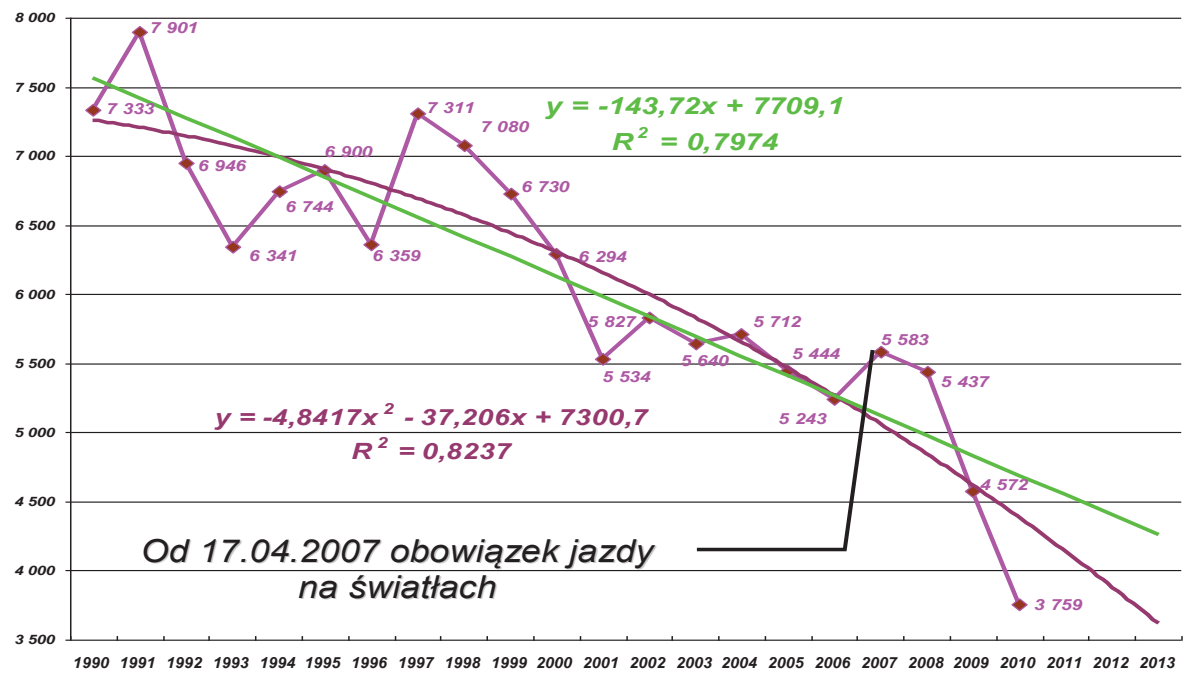

Wykres 1. Zabici w wypadkach drogowych w Polsce wraz z prognozą do $2013 \mathrm{r}$. Źródło: M. Żuber, 2010, s. 460.

Skorygowany współczynnik determinacji ${ }^{2}$ dla ofiar śmiertelnych w wypadkach od 1990 do 2010 r. kształtuje się na poziomie ok. 80\%, natomiast wielomianowej funkcji na poziomie ok. 82\% wartości współczynnika determinacji liniowej $\mathrm{R}^{2}$, przy średniorocznej malejącej liczbie na poziomie ok. 144 ofiar śmiertelnych. Błąd estymacji jest na poziomie ok. 461, a odchylenie obserwacji teoretycznych od rzeczywistych na poziomie ok. $8 \%$ liczby ofiar.

Reczywiste wartości rozpatrywanej liczby ofiar śmiertelnych mogą się odchylać od wyznaczonej prognozy średnio o wartość \pm 519 . W 2013 roku przeciętna liczba ofiar może się różnić od prognozowanej o ok. 11\%.

Reasumując, na podstawie przebiegu obu linii (wykres 2) jak również dopasowania procentowego należy sądzić, że w kolejnych latach winien następować dalszy spadek liczby ofiar śmiertelnych w wypadkach drogowych.

2 Informacje na temat sposobu wyboru funkcji trendu można znaleźć m.in. w pracy M. Osińska, 2007, rozdz. 9 


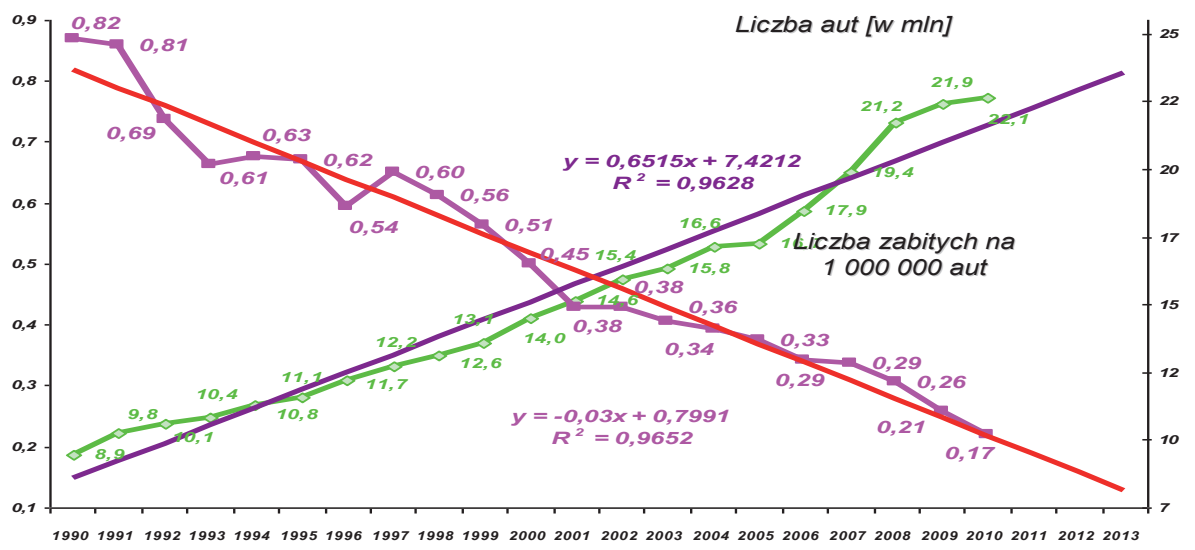

Wykres 2. Zabici w wypadkach drogowych na 1000000 aut w Polsce wraz z prognozą do $2013 \mathrm{r}$.

Źródło: Z. Pietras R. Dołkowski, 2010, s. 807.

Według danych Komendy Głównej Policji, jak również danych statystycznych GUS $^{3}$ od szeregu lat utrzymuje się tendencja spadkowa w liczbie zabitych w wypadkach samochodowych. W celu poprawy sytuacji i dalszego obniżania tej liczby od 2007 r. wszedł obligatoryjny nakaz jazdy na światłach przez całą dobę. Znalazły się jednak osoby, które kwestionowały ten wymóg (pytanie, dla jakich celów?). Przedstawiano nie do końca wiarygodne dane, nieuwzględniające zwiększającej się liczby samochodów (Pietras, Dołkowski, 2010, s. 807), przy niekoniecznie najlepszych drogach.

Dlatego z logistycznego punktu widzenia najwyższy czas, by przy budowie ciągów komunikacyjnych uwzględnić:

- obwodnice dla miast w celu odciążenia dróg śródmiejskich,

- pasy techniczne aby umożliwić dojazd służb ratunkowych,

- zatoczki techniczne, na obwodnicach miast,

- wykorzystać technologie zapewniające dłuższą żywotność dróg (obecne winny wytrzymywać 8-12 lat, a wytrzymują 5-8 lat),

- wdrożyć systemy kontroli od projektowania przez budowę, a na eksploatacji kończąc,

3 Rocznik Statystyczny GUS 1996, s. 445; RS GUS 1997, s. 419; RS GUS 2000, s. 405; RS GUS 2003, s. 443; RS GUS 2006, s. 532; RS GUS 2008, s. 534. 
- budować autostrady po 3-4 pasy ruchu w jedną stronę, (środków finansowych powinno wystarczyć z podatków VAT i CIT od paliw, tj. ok. 60 mld rocznie),

- zakazać ruchu w mieście pojazdów wysokotonażowych, a centra logistyczne przewidywać na obrzeżach miast, tak aby były skomunikowane wszystkimi możliwymi środkami komunikacji dalekosiężnej,

- wszelkie prace na drogach w mieście wykonywane winny być w systemie trzyzmianowym $\mathrm{w}$ dni wolne $\mathrm{i}$ weekendy, w pozostałe dni na nocnej zmianie, kiedy ruch jest najmniejszy (a co za tym idzie i mniejsze straty dla skarbu państwa).

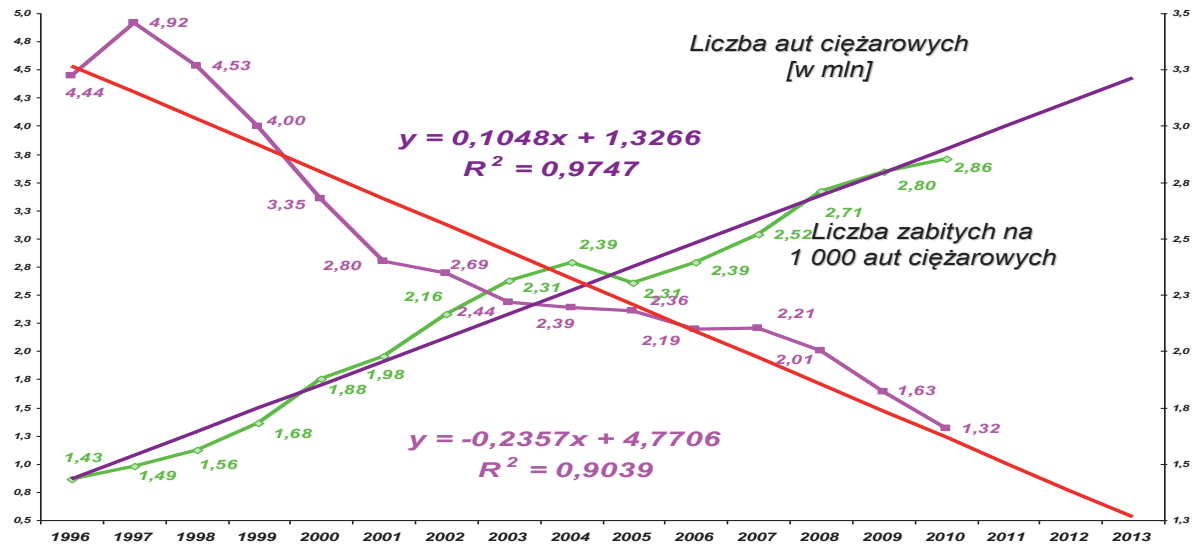

Wykres 3. Zabici w wypadkach drogowych na 1000 aut ciężarowych w Polsce wraz z prognozą do $2013 \mathrm{r}$.

Źródło: Z. Pietras R. Dołkowski, 2010, s. 807.

Co mogą zrobić społeczności lokalne, organizacje społeczne i obywatele? Przede wszystkim powinny:

- mobilizować rząd do poprawy bezpieczeństwa;

- rozpoznawać lokalne problemy:

- instalować zwalniacze prędkości jako przejścia dla pieszych, a nie wg często nieracjonalnych partykularnych koncepcji;

- pomagać i nadzorować;

4 Oprac. na podst. materiałów I Światowego Tygodnia Bezpieczeństwa Ruchu Drogowego 23-29.04.2007 r. 
- planować bezpieczne rozwiązania drogowe (nieograniczające się jedynie do ograniczeń prędkości, a do realnego zapewnienia bezpieczeństwa);

- realizować odbiór inwestycji drogowych (tak aby spełniały one normy jakościowe i kryteria bezpieczeństwa);

$\checkmark$ realizować programy bezpieczeństwa dzieci w wieku szkolnym,

$\checkmark$ egzekwować przepisy bezpieczeństwa ruchu,

$\checkmark$ stosować ograniczenia prędkości tam, gdzie są one niezbędne,

- popierać egzekwowanie natychmiastowych kar za wykroczenia.

Istotną rolę, zwłaszcza w fazie reagowania kryzysowego podczas katastrof $i$ innych zdarzeń drogowych odgrywa, chyba najlepiej zorganizowany komponent w naszym kraju w postaci krajowego systemu ratowniczo-gaśniczego, który dysponuje odpowiednimi narzędziami i procedurami logistycznymi, w pełni adekwatnymi do radzenia sobie z potencjalnymi zagrożeniami w ruchu drogowym. Szczególnie wyróżnia się tu Państwowa Straż Pożarna, dysponująca możliwościami w zakresie realizacji różnego typu ratownictwa.

\section{PODSUMOWANIE}

Od zarania dziejów ludzie mają do czynienia z sytuacjami kryzysowymi. Wywoływane są sytuacjami przypadkowymi, losowymi, niepowodzeniami oraz porażkami.

Każde wyzwanie stworzone przez określoną sytuację to potencjalne zagrożenie. Jeśli wyzwanie nie zostanie w porę dostrzeżone i nie zostaną podjęte właściwe działania, to może się ono przekształcić w zagrożenie lub w stan kryzysowy, wymagający reagowania kryzysowego.

Jeśli już doszło do kryzysu, to podejmowane czynności wchodzą w obszar zarządzania kryzysowego, czyli działania w sytuacji bezpośredniego zagrożenia. Najistotniejszym parametrem jest wtedy szybkość działania, wynikająca z presji czasu. Organizacja zabezpieczenia logistycznego wszystkich podmiotów uczestniczących w reagowaniu kryzysowym i zwalczaniu jego skutków jest więc nieodłącznym warunkiem sukcesu. Kluczowym elementem logistycznego zabezpieczenia funkcjonowania określonego zespołu zarządzania kryzysowego jest zakres dostaw zaopatrzeniowych. Dobra organizacja powinna zakładać bieżące rozpoznawanie i pokrycie potrzeb ilościowo-jakościowych w miejscu zdarzenia na podstawowe produkty logistyczne. Faza odbudowy wymaga odtworzenia elementów infrastruktury krytycznej 
przywracającej naruszony porządek i bezpieczeństwo publiczne. Zanim nastąpi sytuacja kryzysowa, konieczne jest pozyskanie niezbędnych zasobów logistycznych do zabezpieczenia prowadzonych akcji ratowniczych i działań operacyjnych.

Wystąpienie sytuacji kryzysowej wynikającej między innymi z zagrożeń przedstawionych w tym materiale może doprowadzić do zdezorganizowania życia codziennego obywateli, spowodować przeciążenia lub załamanie administracji, a także infrastruktury państwa. Wymusza to na organach państwa ponoszących odpowiedzialność za bezpieczeństwo zewnętrzne i wewnętrzne konieczność mobilizacji wszelkich dostępnych środków umożliwiających zapobieganie dalszemu rozwojowi sytuacji kryzysowej, a także obowiązek likwidacji zaistniałych skutków.

Reasumując, należy stwierdzić, iż logistyka w sytuacjach kryzysowych spowodowanych zagrożeniami w ruchu drogowym nakierowana jest przede wszystkim na niesienie pomocy tym, którzy są poszkodowani w wyniku różnorodnych zdarzeń, a także awarii technicznych na drodze. Skuteczność realizowanych procesów logistycznych zależy od podejmowanych decyzji, uwzględniających uwarunkowania wynikające z właściwej diagnozy sytuacji kryzysowej, analizy sytuacji, oceny sił i środków, niezbędnych do reagowania. Wypracowanie tych decyzji powinno zaowocować realizacją zadań w zakresie:

- przepływu dóbr rzeczowych i usług w każdej fazie zarządzania kryzysowego;

- utrzymania zapasów na niezbędnym poziomie;

- ewakuacji ludzi i mienia z terenów zagrożonych w wyniku katastrof lub innych zdarzeń w ruchu drogowym;

- prowadzenia prac inżynieryjnych związanych z odtwarzaniem sprawności obiektów infrastruktury drogowej;

- usuwania zawałów i osuwisk gruntów na drogach;

- doraźnej odbudowy (remontu) dróg;

- tworzenia infrastruktury strumieni logistycznych;

- realnej ewaluacji kosztów logistycznych;

- właściwej wymiany informacji, zwłaszcza w kontekście terminowego i rzetelnego informowania zagrożonej ludności. 


\section{LITERATURA}

Gapiński Sz., Krystek R. (2008), Bezpieczeństwo transportu, „Magazyn Autostrady”, $\mathrm{Nr} 10$.

Homplewicz J. (1996), Przepisy ramowe polskiego kodeksu drogowego, Wrocław.

Maslow A.H. (1943), A Theory of Human Motivation, „Psychological Reviev”, t. 50.

Nowak E. (2005), Logistyka w sytuacjach kryzysowych, AON Warszawa, Warszawa.

Nowak E. (2008), Zarzadzanie logistyczne w sytuacjach kryzysowych, AON, Warszawa.

Nowak W., Nowak E. (2009), Podstawy logistyki w sytuacjach kryzysowych z elementami zarządzania logistycznego, Społeczna Wyższa Szkoła Przedsiębiorczości i Zarządzania, Łódź-Warszawa.

Osińska M., (red.) (2007), Ekonometria współczesna, Wyd. Dom Organizatora, TNOiK, Toruń.

Pieprzny S. (2007), Ochrona bezpieczeństwa i porzadku publicznego w prawie administracyjnym, Rzeszów.

Pietras Z., Dołkowski R. (2010), Bezpieczeństwo w transporcie drogowym jako problem, „Logistyka” nr 2/2010, Polit. Radomska, Radom.

Rajchel K. (1975), Prawo drogowe, Wydawnictwo Komunikacji i Łączności, Warszawa.

„Rocznik Statystyczny GUS” 1996, 1997, 2000, 2003, 2006, 2008.

Słownik terminów z zakresu psychologii dowodzenia i zarządzania, Warszawa 2000.

Strelau J. (2003), Psychologia. Podstawy psychologii, Gdańskie Wydawnictwo Psychologiczne, Gdańsk.

Sztompka P. (2002), Socjologia Analiza społeczeństwa, Wyd. Znak, Kraków.

Urban A. (2009), Bezpieczeństwo społeczności lokalnych, Warszawa.

Ustawa o zarządzaniu kryzysowym z dnia 26 kwietnia 2007 r., Dz.U.07.89.590.

Żuber M. (red.), Katastrofy naturalne i cywilizacyjne. Różne oblicza bezpieczeństwa, wyd. WSOWLąd, Wrocław, 2010, Pietras Z., Ekonomiczne i logistyczne aspekty wypadków $w$ transporcie drogowym. 


\title{
LOGISTICS IN CRISIS MANAGEMENT
}

\begin{abstract}
A bstract. The article presents selected elements of logistics in crisis management. The concept of categorization of all potential hazards is introduced along with detailed division of the dangers caused by natural disasters. The article also discusses selected elements of crisis management in road traffic focusing on the period of 1990-2010 and presenting the forecast of traffic fatalities for the year of 2013.
\end{abstract}

K e y w o r d s: logistics, crisis, crisis management, hazards, natural disasters. 